\title{
DURABILITY OF CONCRETE WITH BINDER BASED ON SULFOCALCIC FLY ASH
}

\author{
Rostislav ŠulC*, Matouš Krása, Petr FormáčEK \\ Czech Technical University in Prague, Faculty of Civil Engineering, Department of Construction Technology, \\ Thákurova 7/2077, 16629 Prague 6, Czech Republic \\ * corresponding author: rostislav.sulc@fsv.cvut.cz
}

Abstract. This paper deals with the durability of concrete with binder based on sulfocalcic fly ash. At the beginning, in the theoretical part, there is a research on the frost resistance of concrete, its resistance to chemical thaw substances and measures to extend the durability of the concrete. There is also a part about sulfocalcic fluid fly ash and concrete. Practical part is devoted to individual input materials and experimental procedures. There is also described the methodology of the design of the individual mixtures and the results from the tests and their comparison.

KEYwords: FBC fly ash, durability, chemical thaw substances, compressive strength.

\section{INTRODUCTION}

We often hear topics about the environment, waste management and recycling in the media. The power industry is one of the leading industries in the production of waste materials. It is 13.7 million tons (2014) of the secondary energy product produced in the Czech Republic in one year [1]. These are wastes from thermal power plants and heat plants, specifically fly ash, slag, ash and products generated during flue gas desulphurization. Attempts are currently being made to utilise these products, especially in the construction industry. Fluid ash, which as a by-product is produced by fluidized bed combustion, starts to harden with just mixing with water. The work is based on previous publications dedicated to concrete based on sulfocalcic fly ash [2]. The main point is the resistance of these concrete to chemical thaw substances, where concrete of this type did not meet the requirements of the standards. Specifically, it is the preparation of a mixture designed for the construction of a concrete road panels in the categories CB I, CB II and CB III 3.

\section{Concrete Resistance against FREEZING CYCLES}

The topic of frost resistance and resistance of concrete against chemical thaw substances is a very actual. Individual stages of environmental aggression are defined. It depends on the conditions in which concrete is located and we can simply define the requirements for concrete [5]. Among other things, this standard specifies the following requirements for the properties and composition of the concrete mixture: maximal water coefficient, minimal amount of cement, minimal strength class, minimal air pores content and requirements for used aggregate [4].

\subsection{TheOrY of DEGRADATION PROCESSES DUE TO FROST}

The mechanism of degradation processes is complicated and ambiguous. There are many theories that differ from each other. The cause is the tension which is caused by the increase in volume of changing water to ice. But this statement is very inaccurate. The pore system of the concrete is very complex and consists of a system of macropores (gel, capillary, air) that are differently saturated with water. In these pores water changes in ice at different temperatures. Water does not convert to ice even at -30 to $-40^{\circ} \mathrm{C}$ in some pores. The gradual formation of ice creates a hydraulic pressure, that forces the water into the capillary system. The degradation of the concrete body occurs if the pressure is greater than the tensile strength of the cement matrix. We also have to take consideration of theories based on thermal expansion of aggregate, cement matrix and ice [5].

There are many theories for the degradation process of frost due to chemical thaw substances. It is referred as salt scaling. It must meet the following characteristics to consider any mechanism as the cause of this type of degradation:

(a) Degradation consists in the gradual removal of small fragments of sealant.

(b) Worst condition is usage of a solution of $\sim 3 \%$ (independent of the type of solution we use).

(c) There is no peeling if there is no layer of solution on the surface.

(d) Degradation does not occur if the minimum temperature is above $-10^{\circ} \mathrm{C}$. The amount of damage increases when the minimum temperature drops below $-10^{\circ} \mathrm{C}$.

(e) Aeration improves durability. 


\begin{tabular}{lcccc}
\hline Degree of environmental impact & XF1 & XF2 & XF3 & XF4 \\
Maximal water coefficient w/c [ - ] & 0.55 & 0.55 & 0.50 & 0.45 \\
Minimal strength class & C $30 / 37$ & $\mathrm{C} 25 / 30$ & $\mathrm{C} 30 / 37$ & $\mathrm{C} 30 / 37$ \\
Minimal amount of cement [kg/m $\left.\mathrm{m}^{3}\right]$ & 300 & 300 & 320 & 340 \\
Minimal air pores content [\%] & - & 4.0 & 4.0 & 4.0 \\
\hline
\end{tabular}

TABLE 1. Requirements for properties and composition of concrete according to EN 206 4.

(f) The salt concentration in the solution layer on the surface is more important than the salt concentration in the pores.

(g) Susceptibility to salt peeling is unrelated to the susceptibility to internal frost.

(h) Surface strength determines the ability to resist the peeling of concrete due to salt 6 .

The main cause of salt scaling and the mechanism that meets all these characteristics is called glue spalling. This designation is used originally for the glass decoration method, which explains the mechanism of concrete peeling. This method consists of sandblasting and subsequent application of high temperature epoxy. The formed composite is then cooled. It cracks and creates a tensile stress around the perimeter of cracks because of a larger shrinkage of the epoxide. This results in the peeling off thin glass flaps. It is a composite made of concrete itself and a frozen salt solution on its surface in the case of basic concrete. Frozen solution starts to shrink five times more than the concrete if the temperature drops below its melting point. The stress results in the rupture of a certain layer of ice. These cracks penetrate the cement sealant and continue parallel to the composite interface. Then some of the concrete is peeled off 7 .

\subsection{MEASURES TO INCREASE THE RESISTANCE OF CONCRETE AGAINST CHEMICAL THAW SUBSTANCES}

The simplest measure is not to expose the concrete to such an environment. But this is usually not possible. There are measures that help to increase and protect the concrete from degradation.

Aerating additives - We increase concrete resistance to chemical thaw substances by aeration. We must keep a spacing factor of less than $300 \mu \mathrm{m}$ to achieve adequate resistance. Aeration reduces the bleeding of the concrete and increases surface strength of concrete. Bleeding causes a different density of concrete in its cross section. The greatest value occurs at the bottom. These changes in density correspond to the strength changes and concrete has the smallest strength on the surface. The resulting air bubbles will stick to the cement particles and allow them to move upward. Initial frost in the resulting air bubbles causes suction in the pore fluid. This suction results in compression of the skeleton of pores, which reduces the stress caused by thermal expansion to one-third. The mixture should have a pores content with a diameter of less than $300 \mu \mathrm{m}$ greater than $1.5 \%$ [6] 8 .

The water coefficient - The water factor has a great effect on the durability of the concrete (strength, permeability), decreasing bleeding and increasing strength while decreasing $\mathrm{w} / \mathrm{c}$ ratio and achieving greater resistance to salt scaling. Concrete with low water coefficient (up to 0.3) do not need to be aerated and its bleeding is very small. It corresponds to concrete with $\mathrm{w} / \mathrm{c}=0.45$ and $20 \%$ air [6, 8, 9]. A compressive strength of about 40-45 MPa should be achieved for aerated concrete to be resistant against chemical thaw substances at a conventional water coefficient of 0.4 to 0.45 [6].

Aging conditions - The longer the concrete treatment in wet conditions, the higher the strength will be. Exposing the concrete to high temperatures for a short time immediately after mixing results in a decrease in resistance to chemical thaw substances [6]. The high temperature during aging of concrete has a negative effect on the resistance of concrete against chemical thaw substances as it reduces its strength [6. It has been proven in concrete that a longer wet treatment period has a positive effect on resistance [10, 11]. Subsequent drying at room temperature has no significant effect. The resistance will deteriorate due to the weakening of the concrete surface if the temperature is higher. This weakening can also cause drying at relative humidity less than $30 \%$ [6].

Sealing mixtures - "Sealers" only delays the onset of degradation. In some cases, subsequently resulting in sudden and significant drop off generation [6]. When testing three different types of sealants, the resistance test was only delayed by moisture absorption due to the created hydrophobic surface [12]. The moisture content of the treated sample was almost equal to the untreated after one day of immersion and the difference was zero after three days. Even with the use of similar silicone treatment preparations [13. This corresponds to avoiding the degradation during the first 5 to 10 days thaw cycles, but this does not mean that the treatment agent prevents moisture from entering. As mentioned above, the treatment preparations only postpone the onset of degradation but do not affect the resistance to chemical thaw substances [6]. 


\section{Concrete With BINDER BASED ON SULFOCALCIC FLY ASH}

Ashes are made from the combustion of coal in thermal power plants. They are non-combustible inorganic admixtures. The amount of these materials increases with decreasing quality of coal. Different types of ash are distinguished depending on the type of combustion chamber, such as high temperature or sulfocalcic fly ash [14, 15].

\subsection{FLUID COMBUSTION}

This is a modern method of combustion based on the fluidization effect. It consists of heating inert material (ash or quartz sand, etc.) to the temperature of combustion of fuel and the flow of air to achieve a fluid state of bulk material. Liquid properties are used in fluidized fireplaces, hence transferring heat between the liquid and the heating surface. It results in a better heat transfer coefficient than in other types. Different types of fuels can be burned. A small amount of limestone is added to the fluidized bed to prevent formation of $\mathrm{SO}_{3}$ and to reduce the exhaust of nitrogen oxides. Fluid boilers are divided into atmospheric and pressure vessels. Atmospheric is further divided into stationary fluid boilers and circulating boilers [15 17].

\subsection{SulfoCAlCIC FLY ASH}

The difference is both chemical and mineralogical between sulfocalcic fly ash and classic fly ash. Fluid fly ash contains up to 20 wt. $\% \mathrm{SO}_{3}$, up to 15 wt.\% free high reactive $\mathrm{CaO}$, and occasionally exhibits greater annealing losses of up to 15 wt.\%. When the sulfocalcic fly ash is mixed with water solidification and hardening occur due to the presence of anhydrite and free lime. Sulfocalcic fly ash cannot be evaluated according to EN 450-1 or EN 450-2 due to non-fulfilment of the characteristics on fly ash used in concrete and most technical criteria [18].

\section{Concrete With Binder Based ON SULFOCALCIC FLY ASH}

Experiments were carried out on concrete in which fly ash was used as a binder [2. Specifically, it was a sulfocalcic fly ash from the Tisova power plant. Part of the series had a binder composed of sulfocalcic bed and fly ash, referred to as ETH10. As a filler was used aggregate composed of three fractions (0-4, 4-8, 8-16). Mixtures were not aerated and plasticizing additive GLENIUM ACE 40 was used in a ratio of $1.575 \%$ of fly ash to achieve better consistency. Testing was performed on $100 \mathrm{~mm}$ cubes.

Strength - Compressive strength increases with longer grinding time. Between the non-milled binder and the 45-minute milling was a significant difference of 27.38 MPa, as shown in the table (Tab. 2] [2].

Resistance against chemical thaw substances - A comparison of two series was made. These series differed only in the water coefficient (B-FPC $57 \mathrm{w} / \mathrm{c}=$
0.4575$, B-FPC $48 \mathrm{w} / \mathrm{c}=0.4025)$. With a decreasing water coefficient, the resistance to chemical thaw substances increases, despite they achieved almost the same strength 2]. The values of the resistance of the series using ETH10 binders (B-FPC: 57, 58, 59, 64) are recorded in the following table (Tab. 3). As can be seen, requirement of standard for waste generation $1000 \mathrm{~g} / \mathrm{m}^{2}$ at 75 cycles for CB II or 100 cycles for CB I does not meet any mixture. Among other things, with a longer time of grinding the amount of waste decreases.

\section{EXPERIMENTAL PROCEDURES}

This part will describe the used materials and their properties and the design methodology and composition of individual samples.

\subsection{MATERIALS}

Aggregate consisting of three fractions is used is a filler: 0/4, 4/8, 8/16. Aggregate consists from sand component originating from Dobrin and coarse fractions of crushed aggregate, which are from the Zbraslav quarry. The percentage of individual fractions was determined using the Kennedy - Bolomey curve [20]. Due to the appreciable absence of the sand fraction in the aggregate, the adjustment of the ratios was made even though the aggregate curve crosses the standard centre line (Fig. 1). The resulting ratios are listed in the following table (Tab. 4).

Sulfocalcic fly ash - Fly ash comes from Ledvice coal-fired power station. This is a bed fluid fly ash. The sample of non-grinded fly ash was sent to the XRF laboratory (Tab. 5). The order of representation of the individual elements is consistent with the ETH10 ash used in the previous work. Percentage is different up to $4 \%$. The biggest difference is in the $\mathrm{SiO}_{2}$ content, which is $3.81 \%$ less in ETH 10. Additionally, ETH 10 has $2.67 \%$ more $\mathrm{TiO}_{2}, 2.4 \%$ more $\mathrm{SO}_{3}$ and $2.26 \%$ less $\mathrm{CaO}$. The remaining elements do not differ by more than $2 \%$ [2].

The ash was ground for 45 minutes in the tumbling mill 0M20f consisting of a rotating drum and grinding charge. In this case, the grinding charge is a mixture of spheres of different diameters $(\varnothing 17 \mathrm{~mm}-20 \mathrm{~kg}$, $\varnothing 30 \mathrm{~mm}-20 \mathrm{~kg}, \varnothing 50 \mathrm{~mm}-20 \mathrm{~kg}$ ) with a total weight of $90 \mathrm{~kg}$. The mill is controlled by a computer, where the rotating speed of the drum (rpm) and the time for grinding and emptying are set on the touch screen [21]. A sample was taken from the non-ground ash ELE - LO - 0 and the ground mixture ELE - LO - IV to determine granulometry (Tab. 6. Fig. 2, Fig. 3 ).

ETH 10 fly ash, used in previous experiments, had $d_{50}=230.6 \mu \mathrm{m}$ in the non-ground state. A value is less than that of non-grinded ELE-LO fly ash, which had $d_{50}=275.4 \mu \mathrm{m}$. As well as for the ground fly ash. For ETH 10 - IV value of $d_{50}$ was $9.3 \mu \mathrm{m}$ and ELE LO - IV only with $d_{50}=14.1 \mu \mathrm{m}[2$.

Ingredients - Superplasticizing and aerating additives were used in the experiment. Glenium ACE 40 


\begin{tabular}{lcccc}
\hline Series & Binder & $\begin{array}{c}\text { Compressive strength } \\
\text { 28 days [MPa] }\end{array}$ & Grinding time [min] & Water coefficient [ - ] \\
\hline B-FPC 57 & Tisova ETH 10 & 62.9 & 45 & 0.458 \\
B-FPC 59 & Tisova ETH 10 & 35.5 & 0 & 0.460 \\
B-FPC 64 & Tisova ETH 10 & 54.9 & 15 & 0.458 \\
\hline
\end{tabular}

TABLE 2. Features of the B-FPC series 57, 59, 64 [19].

\begin{tabular}{|c|c|c|c|c|c|c|c|c|c|}
\hline \multirow{3}{*}{ Series } & \multirow{3}{*}{$\begin{array}{l}\text { Sample age } \\
\text { [days }]\end{array}$} & \multicolumn{8}{|c|}{ Chemical thaw substances resistance } \\
\hline & & \multirow{2}{*}{\multicolumn{2}{|c|}{$\begin{array}{l}25 \text { cycles } \\
{[\mathrm{g}] \quad\left[\mathrm{g} / \mathrm{m}^{2}\right]}\end{array}$}} & \multicolumn{2}{|c|}{50 cycles } & \multicolumn{2}{|c|}{75 cycles } & \multicolumn{2}{|c|}{100 cycles } \\
\hline & & & & {$[\mathrm{g}]$} & {$\left[\mathrm{g} / \mathrm{m}^{2}\right]$} & {$[\mathrm{g}]$} & {$\left[\mathrm{g} / \mathrm{m}^{2}\right]$} & {$[\mathrm{g}]$} & {$\left[\mathrm{g} / \mathrm{m}^{2}\right]$} \\
\hline B-FPC 57 & 153 & 50.0 & 2873.4 & 102.9 & 5475.4 & & & & \\
\hline B-FPC 58 & 146 & 14.2 & 770.1 & 29.8 & 1616.2 & 42.4 & 2299.6 & 81.7 & 4431.1 \\
\hline B-FPC 59 & 139 & 189.5 & 9036.7 & 471.4 & 22479.7 & & & & \\
\hline B-FPC 60 & 139 & 70.2 & 2575.4 & 174.5 & 6401.8 & & & & \\
\hline B-FPC 61 & 118 & 88.7 & 2914.9 & 202.0 & 6638.2 & & & & \\
\hline B-FPC 62 & 111 & 21.6 & 945.3 & 41.7 & 1824.9 & 70.6 & 3089.6 & 81.8 & 3579.7 \\
\hline B-FPC 63 & 111 & 362.0 & 12387.1 & 694.4 & 23829.7 & & & & \\
\hline B-FPC 64 & 104 & 89.7 & 3860.6 & 212.4 & 9141.4 & & & & \\
\hline
\end{tabular}

TABLE 3. Results of the chemical thaw substances resistance tests [19].

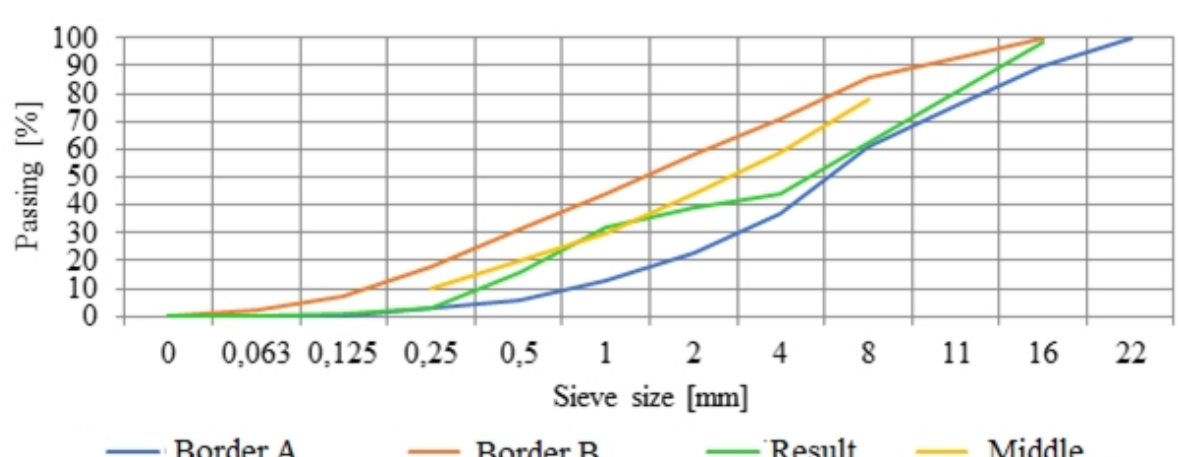

Figure 1. Design of aggregate according to Kennedy Bolomey curve.

\begin{tabular}{cc}
\hline Fraction of aggregate & Quantity [\%] \\
\hline $0-4$ & 42 \\
$4-8$ & 18 \\
$8-16$ & 40 \\
\hline
\end{tabular}

TABle 4. Aggregate composition.

\begin{tabular}{ccccccc}
\hline \multicolumn{7}{c}{ ELE - LO - 0 } \\
\hline $\mathrm{SiO}_{2}$ & $\mathrm{Al}_{2} \mathrm{O}_{3}$ & $\mathrm{CaO}$ & $\mathrm{SO}_{3}$ & $\mathrm{Fe}_{2} \mathrm{O}_{3}$ & $\mathrm{TiO}_{2}$ & $\sum$ \\
$34.16 \%$ & $27.97 \%$ & $21.48 \%$ & $7.89 \%$ & $3.94 \%$ & $2.56 \%$ & $98.00 \%$ \\
\hline
\end{tabular}

TABLE 5. XRF - chemical composition of fly ash ELE - LO.

\begin{tabular}{lcc}
\hline $\mathrm{R}=50 \%$ & ELE-LO-0 & ELE-LO-IV \\
\hline$d_{R}[\mu \mathrm{m}]$ & 275.374 & 14.067 \\
\hline
\end{tabular}

TABLE 6. Granulometry of the sample and ground sample. 


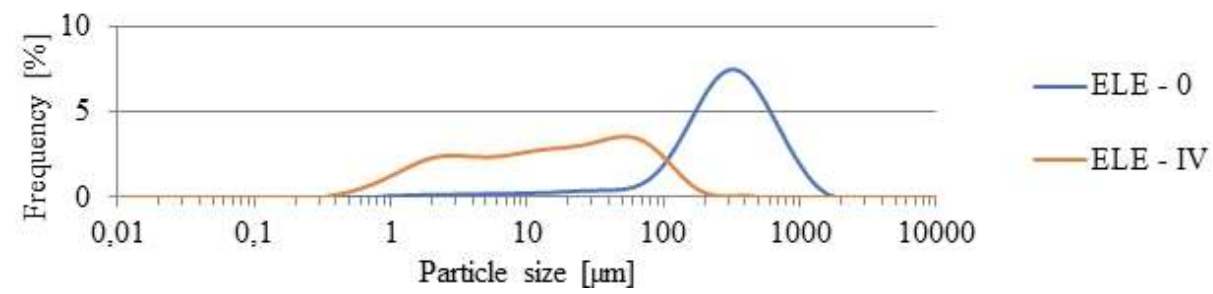

Figure 2. Fly ash granulometry - frequency of particle size.

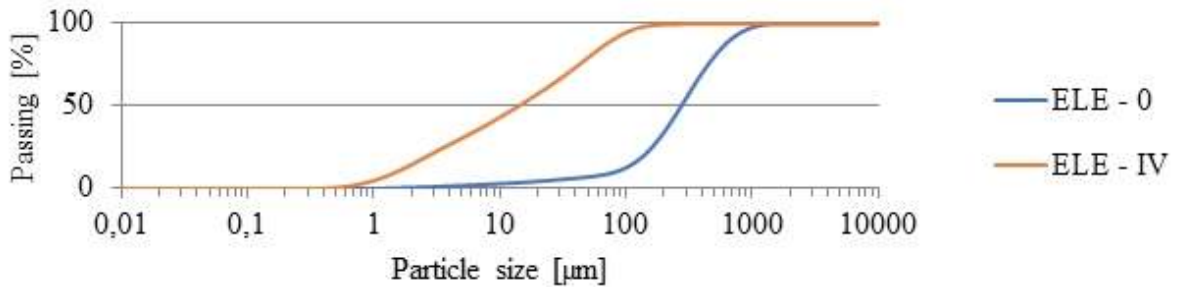

FIGURE 3. Fly ash granulometry - passing.

superplastifying admixture from BASF is composed of polycarboxyether polymers. It accelerates the hydration of cement due to its molecular alignment. The recommended effective dosage is from $0.6 \%$ to $1.0 \%$ of the weight of the cement. Specific dosages are chosen depending on the requirements for processability, type of cement and production technology. GLENIUM ACE 40 is applied during mixing, ideally after all ingredients and at least $80 \%$ of the mixing water have been added [22. The MISCHÖL LP 78 (now referred to as MASTER AIR 178) is a synthetic aerating additive. It reduces the surface tension of the mixing water. It achieves good plasticisation and better cohesion of the mixture. The dosage depends on the desired workability, the type of cement, the production technology. The effective dose ranges from $0.05 \%$ to $1.5 \%$ [23.

\subsection{OPtIMIZING AERATION ADDITIVES}

The amount of aeration additives was optimized in series no. 10. A total of 6 mixtures with different ingredient contents were made. Aeration were from 0 to $2.5 \%$ and the dosage was increased by $0.5 \%$. The MISCHÖL LP 78 was used as an aerating ingredient. The individual mixtures were identical. The dose of aerating ingredient was only thing that changed. The partial composition of each mixture is given in the table below (Tab. 7).

The series no. 12 was selected as a second mixture for the subsequent chemical thaw substances resistance testing. The aeration was carried out in the same way as in the $10^{\text {th }}$ series. Variable is again a dose of aerating additives. There is a lower water factor compared to series no. 10, but it is used $0.5 \%$ more plasticizing additive. We can compare the effects of these parameters to the final test values. The composition of individual mixtures in series no. 12 is given in the next table (Tab. 8).

\section{Results AND DISCUSSION}

This part is devoted to the results of the different series and their mutual comparison, depending on the different composition and properties. These are the results of concrete slump test (consistency), air content in fresh mixture, compressive strength, and resistance of concrete based on sulfocalcic fly ash against chemical thaw substances.

\subsection{Consistency}

This test is based on EN 12350-2. The results of slump tests are shown in the following graph (Fig. 4).

The consistency of series no. 10 is as expected. The slump is growing with the increasing amount of MISCHÖL LP 78 additive. The steep slope of the curve at the beginning from 0 to $1 \%$ is interesting, especially between $0.5 \%$ and $1 \%$, where the $105 \mathrm{~mm}$ gap is observed. Series no. 12 also show this increasing tendency, but there is an abnormality in mixture with an aerosol content of $1.5 \%$. The slump drops from $190 \mathrm{~mm}$ to only $90 \mathrm{~mm}$ and then increases again to $240 \mathrm{~mm}$ at $2 \%$. This special phenomenon has not been explained. It was originally thought to be due to a dry mixer. The mixture was therefore prepared again, but similar slump values were achieved. A greater difference in consistency is achieved with the gradual dosing of the aerating additive in a series with a greater water coefficient and a lower dose of plasticizer.

\subsection{Air CONTENT In FRESh MiXture}

To determine the air content in the fresh concrete mixture, a pressure gauge method was used, the procedure of which is described in the standard EN 12350-7. This method is based on a known volume of air and its pressure, which is connected in a sealed container with the volume of air in the concrete mixture, which is unknown 24. The results from the air content measurements in the fresh concrete mixture are shown in the following graph (Fig. 5). 


\begin{tabular}{|c|c|c|c|c|c|c|c|c|c|}
\hline \multirow{3}{*}{ Sample } & \multicolumn{3}{|c|}{ Aggregate } & \multirow{3}{*}{$\begin{array}{l}\text { Fly ash } \\
\text { ELE- } \\
\text { LO-IV } \\
{[\mathrm{kg}]}\end{array}$} & \multirow{3}{*}{$\begin{array}{c}\text { Water } \\
{[1]}\end{array}$} & \multirow{3}{*}{$\begin{array}{c}\text { GLENIUM } \\
\text { ACE } 40 \\
{[\mathrm{~kg}]}\end{array}$} & \multirow{3}{*}{$\begin{array}{c}\text { MISCHŐL } \\
\text { LP } 78 \\
\\
{[\mathrm{~kg}]}\end{array}$} & \multirow{3}{*}{$\begin{array}{c}\text { Air } \\
\text { content } \\
\\
{[\%]}\end{array}$} & \multirow{3}{*}{$\begin{array}{r}\text { Slump } \\
{[\mathrm{mm}]} \\
\end{array}$} \\
\hline & $0-4$ & $4-8$ & $8-16$ & & & & & & \\
\hline & {$[\mathrm{kg}]$} & {$[\mathrm{kg}]$} & {$[\mathrm{kg}]$} & & & & & & \\
\hline 10_0 & 13.749 & 5.892 & 13.094 & 8.4 & 3.864 & 0.126 & 0.000 & 1.8 & 30 \\
\hline $10 \_0,5$ & 13.749 & 5.892 & 13.094 & 8.4 & 3.864 & 0.126 & 0.042 & 2.8 & 75 \\
\hline 10_1 & 13.749 & 5.892 & 13.094 & 8.4 & 3.864 & 0.126 & 0.084 & 3.7 & 180 \\
\hline $10 \_1,5$ & 13.749 & 5.892 & 13.094 & 8.4 & 3.864 & 0.126 & 0.126 & 3.9 & 200 \\
\hline $10 \_2$ & 13.749 & 5.892 & 13.094 & 8.4 & 3.864 & 0.126 & 0.168 & 3.3 & 210 \\
\hline $10 \_2,5$ & 13.749 & 5.892 & 13.094 & 8.4 & 3.864 & 0.126 & 0.210 & 3.7 & 220 \\
\hline
\end{tabular}

TABLE 7. Composition of mixtures of the Series no. 10.

\begin{tabular}{|c|c|c|c|c|c|c|c|c|c|}
\hline \multirow{3}{*}{ Sample } & \multicolumn{3}{|c|}{ Aggregate } & \multirow{3}{*}{$\begin{array}{c}\text { Fly ash } \\
\text { ELE- } \\
\text { LO-IV } \\
{[\mathrm{kg}]}\end{array}$} & \multirow{3}{*}{$\begin{array}{c}\text { Water } \\
\text { [1] }\end{array}$} & \multirow{3}{*}{$\begin{array}{c}\text { GLENIUM } \\
\text { ACE } 40 \\
\\
{[\mathrm{~kg}]}\end{array}$} & \multirow{3}{*}{$\begin{array}{c}\text { MISCHÖL } \\
\text { LP } 78 \\
\\
{[\mathrm{~kg}]}\end{array}$} & \multirow{3}{*}{$\begin{array}{c}\text { Air } \\
\text { content } \\
\\
{[\%]}\end{array}$} & \multirow{3}{*}{$\begin{array}{r}\text { Slump } \\
{[\mathrm{mm}]} \\
\end{array}$} \\
\hline & $0-4$ & $4-8$ & 8-16 & & & & & & \\
\hline & {$[\mathrm{kg}]$} & {$[\mathrm{kg}]$} & {$[\mathrm{kg}]$} & & & & & & \\
\hline $12 \_0$ & 14.272 & 6.117 & 13.593 & 8.4 & 3.528 & 0.168 & 0.000 & 2.1 & 190 \\
\hline $12 \_0,5$ & 14.272 & 6.117 & 13.593 & 8.4 & 3.528 & 0.168 & 0.042 & 2.9 & 210 \\
\hline $12 \_1$ & 14.272 & 6.117 & 13.593 & 8.4 & 3.528 & 0.168 & 0.084 & 4.5 & 190 \\
\hline $12 \_1,5$ & 14.272 & 6.117 & 13.593 & 8.4 & 3.528 & 0.168 & 0.126 & 5.6 & 90 \\
\hline $12 \_2$ & 14.272 & 6.117 & 13.593 & 8.4 & 3.528 & 0.168 & 0.168 & 5.4 & 240 \\
\hline $12 \_2,5$ & 14.272 & 6.117 & 13.593 & 8.4 & 3.528 & 0.168 & 0.210 & 7.6 & 235 \\
\hline
\end{tabular}

TABLE 8. Composition of mixtures of the Series no. 12.

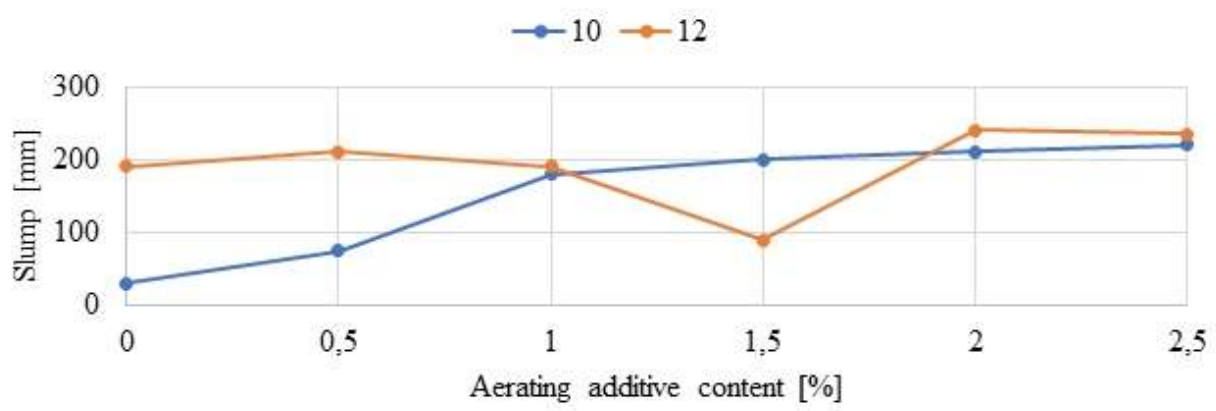

FigurE 4. Series no. 10, 12 - Dependence of the amount of aerating additive on slump.

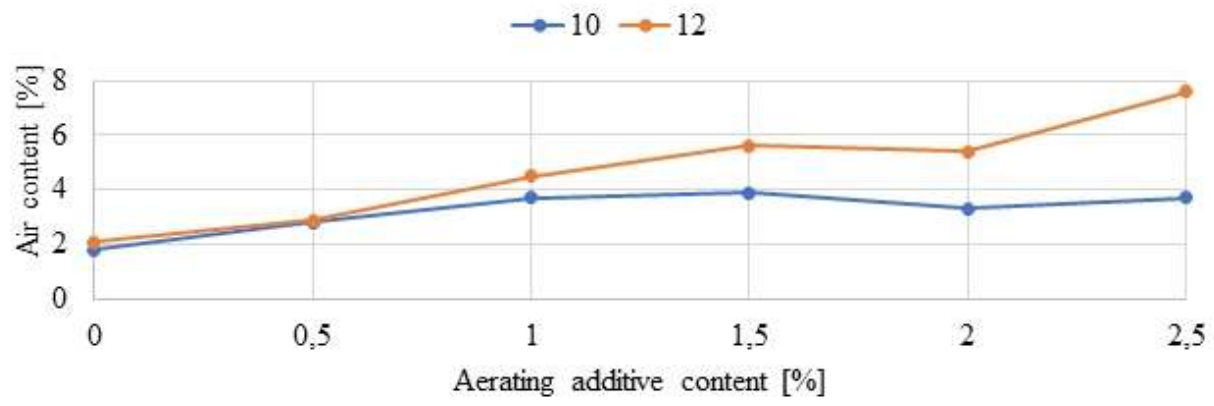

FiguRE 5. Series no. 10, 12 - Dependence of the amount of aerating additive on air content. 
The air content rise with the increasing dose of aerating additive in series no. 10. It increases up to $1.5 \%$ and due to the too high flowability of the mixture afterwards the measured air content stop increasing. The air content of the mixture is gradually increasing in the series no. 12 as expected. There was a slight decrease in air content in fresh concrete mixture at the $2 \%$ of aerating additive content. The final $2.5 \%$ dose reached the highest measured value of all the mixtures produced $-7.6 \%$ of the air content.

\section{Compressive STRENGTH}

Testing the compressive strength of the cubes $(150 \times$ $150 \times 150 \mathrm{~mm}$ ) was based on the test procedure in EN 12390-3. Weighing samples and measuring their height was prior to testing (in the case of samples that increased their volume, all three dimensions were measured). A slider scale was used to calculate the mass of the concrete samples and to determine the surface area [25]. The compression strength results are shown in the graph below (Fig. 6)

The compressive strength decreases as the amount of aerating additive increases as expected. The figure shows a decreasing trend of both curves. The strength decreases even though the measured air content with the increasing dose of aerating additives did not rise. The reason could be the inaccuracy of a pressure method that did not measure the real air content of the fresh mixture. This theory of inaccuracy of the pressure gauge method is confirmed in the following figure of the dependence of compressive strength on the air content (Fig. 7). The samples 10_2 and $10 \_2,5$ were too fluid in the series no. 10 ., which could also have an impact on low air content and possible measurement inaccuracy. The Series no. 12 shows the expected decline in strength with increasing air content.

\subsection{RESisTANCE TO CHEMICAL THAW SUBSTANCES}

Testing of samples for resistance to chemical thaw substances was performed by Method A, which is described in ČSN 731326 [26].

The requirement of standard ČSN 73 6123-1 for the resistance of concrete against chemical thaw substances in method A is for group CB I $1000 \mathrm{~g} / \mathrm{m}^{2}$ after 100 cycles and group CB II $1000 \mathrm{~g} / \mathrm{m}^{2}$ after 75 cycles. All tested samples met both requirements. The measured values were very low, it is necessary to consider measurement inaccuracies.

There is seen the effect of the aeration in the case of series no. 10. The sample without aeration additive has the largest wastes. Other mixtures are difficult to compare due to too little waste difference.

The series no. 12 shows the positive impact of the lower water coefficient compared to the series no. 10 . Only two mixtures were measured with waste. There was no waste generation after 125 cycles even in the sample without aerating additive. Excess doses of
MISCHÖL LP 78 greater than recommended (1.5\%) have a negative effect on resistance against chemical thaw substances.

The compressive strengths of the samples were high enough to exceed the requirements of the C30/37 by standard. The dependence of the amount of waste on compressive strength is not observed (Fig. 10 .

There is no apparent relationship between the air content and the measured waste. High air content of the series no. 12 resulted in greater waste generation. There have been cases where is always one mixture with less or zero waste generation and the other with a higher dose of aerating additives with larger waste generation. Both mixtures had almost the same air content. We can speculate about the accuracy of the measurement of the pressure gauge method or about the possible negative effect of the high dose of aerating additive.

The dependence of increasing doses and decreasing waste amount cannot be seen in the graph. Either no waste or less was measured in samples with fewer aeration additives, than in more aerated mixtures. It is important to find an optimal and effective dose of the additive for the individual mixtures.

\section{Conclusions}

The following findings were observed during the optimization. The air content measurements using the pressure gauge method appeared to be inaccurate. In the optimized mix was a requirement for consistency of S4, which is slump from 160 to $240 \mathrm{~mm}$. This requirement was met with optimal doses of aerating additives in the resulting series no. 10 and no. 12 . With increasing doses of aerating additives, the slump of the mixtures increased. The high consistency of S5 was reached with high doses. The requirement for air content of $4.0 \%$ or $4.5 \%$ was met only in the series no. 12. The desired value was reached in mixture with $1 \%$ of aerating additive. A maximum of air content was $3.7 \%$ in series no. 10 . The compressive strength was greater than the requirements for concrete of the group CB III (C25 / 30) and CB I and II (C30 / 37). Similar results were achieved despite the use of fly ash from another power plant. Compared to the previous work, where a $63 \mathrm{MPa}$ strength of concrete based on sulfocalcic fly ash with a grinding time of 45 minutes was achieved [18]. The resistance against chemical thaw substances by the method A test showed that both series with different aeration levels meet the requirements for concrete. A maximum waste generation of $29.4 \mathrm{~g} / \mathrm{m}^{2}$ was achieved after 100 cycles in the series no. 10. The positive effect of the lower water content and the negative effect due to the too high dose of the aerating agent on the resulting resistance were shown. The previous sulfocalcic fly ash ETH10 has reached a higher levels of waste generation, although with the same granulometry and the chemical representation of the individual elements, A possible 


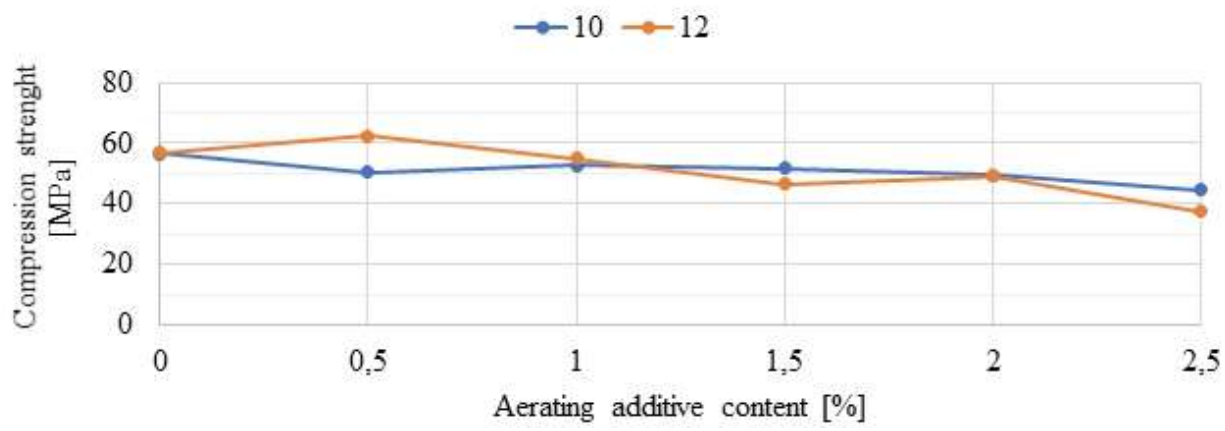

Figure 6. Series no. 10, 12 - Dependence of the amount of aerating additive on compressive strength.

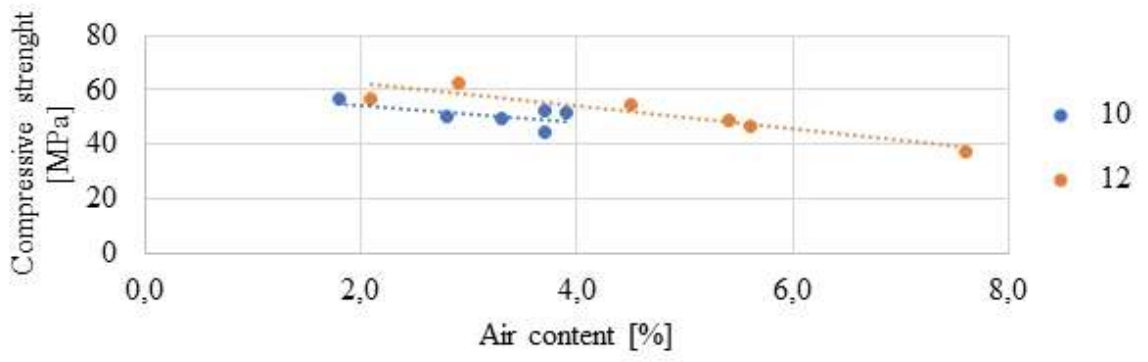

Figure 7. Series no. 10, 12 - Dependence of air content on compressive strength.

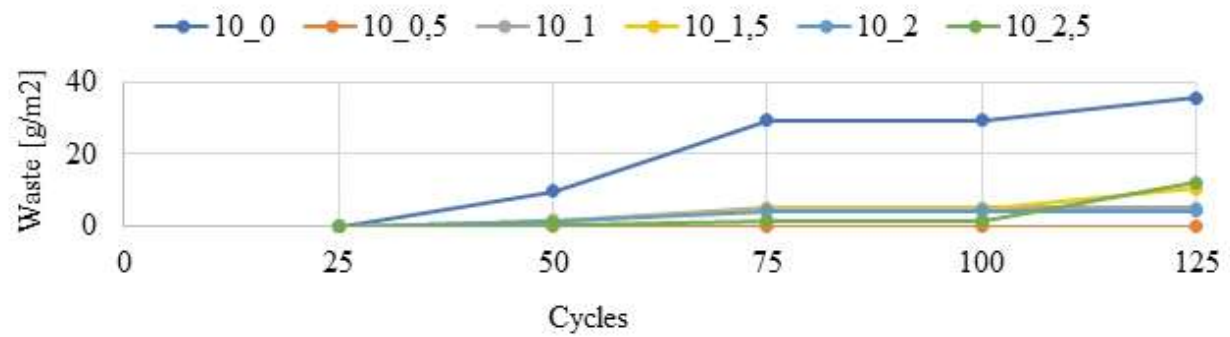

Figure 8. Series no. 10 - Results of the chemical thaw substances resistance tests.

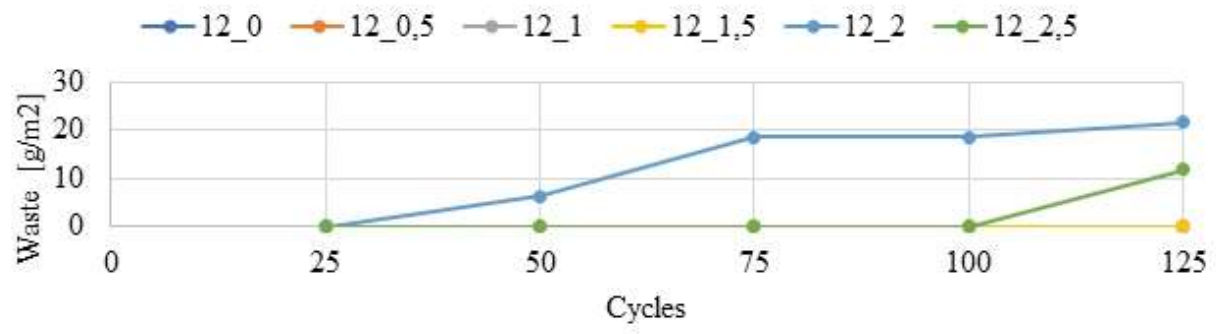

Figure 9. Series no. 12 - Results of the chemical thaw substances resistance tests.

\begin{tabular}{|c|c|c|c|c|c|c|c|c|c|c|c|}
\hline \multirow{3}{*}{ Sample } & \multirow{3}{*}{$\begin{array}{c}\text { Sample } \\
\text { age } \\
\text { [days] }\end{array}$} & \multicolumn{10}{|c|}{ Chemical thaw substances resistance } \\
\hline & & \multicolumn{2}{|c|}{25 cycles } & \multicolumn{2}{|c|}{50 cycles } & \multicolumn{2}{|c|}{75 cycles } & \multicolumn{2}{|c|}{100 cycles } & \multicolumn{2}{|c|}{125 cycles } \\
\hline & & {$[\mathrm{g}]$} & {$\left[\mathrm{g} / \mathrm{m}^{2}\right]$} & {$[\mathrm{g}]$} & {$\left[\mathrm{g} / \mathrm{m}^{2}\right]$} & {$[\mathrm{g}]$} & {$\left[\mathrm{g} / \mathrm{m}^{2}\right]$} & {$[\mathrm{g}]$} & {$\left[\mathrm{g} / \mathrm{m}^{2}\right]$} & {$[\mathrm{g}]$} & {$\left[\mathrm{g} / \mathrm{m}^{2}\right]$} \\
\hline $10 \_0 \_5$ & 34 & 0.0 & 0.0 & 0.3 & 9.8 & 0.75 & 29.4 & 0.75 & 29.4 & 0.91 & 35.7 \\
\hline $10 \_0,5 \_5$ & 34 & 0.0 & 0.0 & 0.0 & 0.0 & 0.00 & 0.0 & 0.00 & 0.0 & 0.00 & 0.0 \\
\hline $10 \_1 \_5$ & 34 & 0.0 & 0.0 & 0.04 & 1.6 & 0.13 & 5.1 & 0.13 & 5.1 & 0.13 & 5.1 \\
\hline $10 \_1,5 \_5$ & 34 & 0.0 & 0.0 & 0.04 & 1.6 & 0.12 & 4.7 & 0.12 & 4.7 & 0.27 & 10.6 \\
\hline $10 \_2 \_5$ & 34 & 0.0 & 0.0 & 0.03 & 1.2 & 0.11 & 4.3 & 0.11 & 4.3 & 0.11 & 4.3 \\
\hline $10 \_2,5 \_5$ & 34 & 0.0 & 0.0 & 0.01 & 0.4 & 0.04 & 1.6 & 0.04 & 1.6 & 0.31 & 12.2 \\
\hline
\end{tabular}

TABLE 9. Series no. 10 - Results of the resistance to chemical thaw substances tests. 


\begin{tabular}{|c|c|c|c|c|c|c|c|c|c|c|c|}
\hline \multirow{3}{*}{ Sample } & \multirow{3}{*}{$\begin{array}{c}\text { Sample } \\
\text { age } \\
\text { [days] }\end{array}$} & \multicolumn{10}{|c|}{ Chemical thaw substances resistance } \\
\hline & & \multicolumn{2}{|c|}{25 cycles } & \multicolumn{2}{|c|}{50 cycles } & \multicolumn{2}{|c|}{75 cycles } & \multicolumn{2}{|c|}{100 cycles } & \multicolumn{2}{|c|}{125 cycles } \\
\hline & & [g] & {$\left[\mathrm{g} / \mathrm{m}^{2}\right]$} & {$[\mathrm{g}]$} & {$\left[\mathrm{g} / \mathrm{m}^{2}\right]$} & [g] & {$\left[\mathrm{g} / \mathrm{m}^{2}\right]$} & {$[\mathrm{g}]$} & {$\left[\mathrm{g} / \mathrm{m}^{2}\right]$} & {$[\mathrm{g}]$} & {$\left[\mathrm{g} / \mathrm{m}^{2}\right]$} \\
\hline $12 \_0 \_5$ & 34 & 0.0 & 0.0 & 0.0 & 0.0 & 0.00 & 0.0 & 0.00 & 0.0 & 0.0 & 0.0 \\
\hline $12 \_0,5 \_5$ & 34 & 0.0 & 0.0 & 0.0 & 0.0 & 0.00 & 0.0 & 0.00 & 0.0 & 0.0 & 0.0 \\
\hline $12 \_1 \_5$ & 34 & 0.0 & 0.0 & 0.0 & 0.0 & 0.00 & 0.0 & 0.00 & 0.0 & 0.0 & 0.0 \\
\hline $12 \_1,5 \_5$ & 34 & 0.0 & 0.0 & 0.0 & 0.0 & 0.00 & 0.0 & 0.00 & 0.0 & 0.0 & 0.0 \\
\hline $12 \_2 \_5$ & 34 & 0.0 & 0.0 & 0.2 & 6.3 & 0.50 & 18.4 & 0.50 & 18.4 & 0.6 & 21.6 \\
\hline $12 \_2,5 \_5$ & 34 & 0.0 & 0.0 & 0.0 & 0.0 & 0.00 & 0.0 & 0.00 & 0.0 & 0.3 & 11.8 \\
\hline
\end{tabular}

TABLE 10. Series no. 12 - Results of the resistance to chemical thaw substances tests.

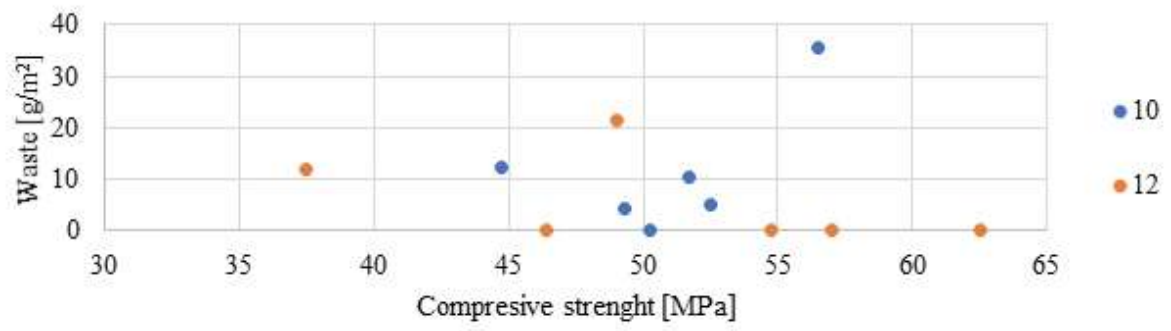

FiguRE 10. Dependence of the amount of waste after 125 cycles on the compressive strength.

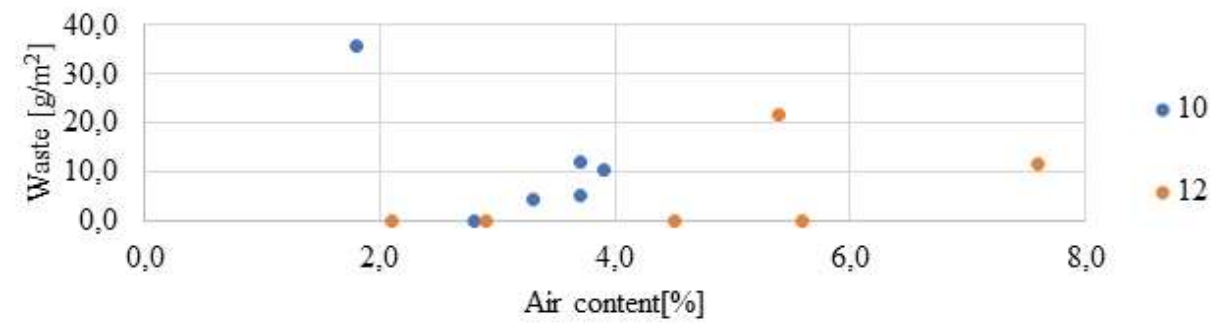

Figure 11. Dependence of the amount of waste after 125 cycles on the air content.

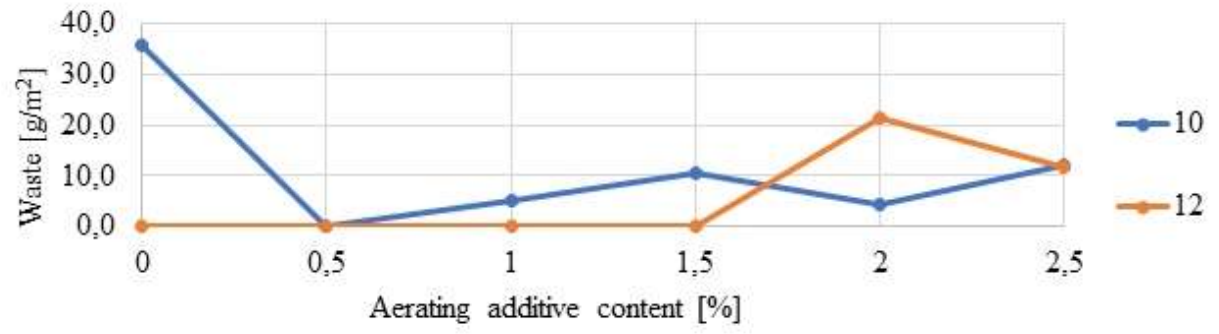

Figure 12. Dependence of the amount of waste after 125 cycles on the amount of aerating additive. 
reason could be the different ash morphology. For this reason, further testing would have to be done.

\section{ACKNowledGements}

This study was part of the research project TH02020163 "Development and industrial optimisation of manufacturing process of construction materials from coal ash for transport construction", FV30062 "Possibilities of utilization of coal-ash from power stations stored at stock piles", SGS16/198/OHK1/3T/11 "Ternary Binders based on Fly Ash from Circulating fluidized Bed Combustion", and we are grateful for cooperation with performed tests provided by the company BASF Stavební hmoty Česká republika s.r.o., Zkušební laboratoř betonu Praha.

\section{REFERENCES}

[1] A. Bilodeau, V. M. Malhotra. ACI Special Publication $S P-132$, chap. Concrete incorporating high volumes of ASTM class F fly ashes: mechanical properties and resistance to deicing salt scaling and to chloride-ion penetration, p. 319-349. American Concrete Institute, Detroit, 1992.

[2] Z. Možíš. FPC betony na bázi upravených sulfátovápenatých popílkü. Master's thesis, Fakulta stavební, ČVUT v Praze, Praha, 2017.

[3] ČSN 73 6123-1, Stavba vozovek - Cementobetonové kryty - Č́st 1: Provádění a kontrola shody. Standard, Úrad pro technickou normalizaci, metrologii a státní zkušebnictví, Praha, 2014.

[4] EN 206, Beton - Specifikace, vlastnosti, výroba a shoda. Standard, Úřad pro technickou normalizaci, metrologii a státní zkušebnictví, 2014.

[5] J. Dohnálek. Vliv mrazuvzdornosti betonu na jeho povrchové úpravy. Beton - Technologie - konstrukce, sanace 3:44-47, 2012.

[6] J. J. Valenza, G. W. Scherer. A review of salt scaling: I. Phenomenology. Cement and Concrete Research 37(7):1007-1021, 2007. DOI:10.1016/j.cemconres.2007.03.005

[7] J. J. Valenza, G. W. Scherer. A review of salt scaling: II. Mechanisms. Cement and Concrete Research 37(7):10221034, 2007. DOI:10.1016/j.cemconres.2007.03.003.

[8] D. N. Richardson. Review of variables that influence measured concrete compressive strength. Journal of Materials in Civil Engineering 3:95-112, 1991. DOI:10.1061/(ASCE)0899-1561(1991)3:2(95)

[9] T. C. Powers. The Properties of Fresh Concrete. John Wiley and Sons, Inc., New York, 1968.

[10] R. Gagne, M. Pigeon, P. C. Aiticin. ACI Special Publication SP-126, chap. Deicer salt scaling resistance of high strength concretes made with different cements, p. 185-199. American Concrete Institute, Detroit, 1992.

[11] M. Lanlois, D. Beaupre, M. Pigeon, C. Foy. ACI Special Publication SP-114, chap. The influence of curing on the salt scaling resistance of concrete with and without silica fume, p. 971-989. American Concrete Institute, Detroit, 1989.
[12] T. Sedrah, T. Pigeon, M. Hazrati. Durability of Building Materials and Components, vol. 6, chap. The influence of penetrating sealers on the deicer salt scaling resistance of concrete, pp. 487-496. E \& FN Spon, London, 1993.

[13] P. Klieger, W. Perenchio. Silicone influence on concrete resistance to freeze-thaw and de-icer damage. Highway Research Record 18:33-47, 1963.

[14] P. Fečko, M. Kušnierová, H. Raclavská, et al. Fly Ash. Ediční středisko VŠB-TU Ostrava, Ostrava, 2005.

[15] M. Topinková. Anorganická pojiva. Fakulta metalurgie a metriálového inženýrství, VŠB-TU Ostrava, Ostrava, 2013.

[16] J. Andreovský. Spalování paliv - kotle, odborné vzdělávání úředníků pro výkon státní správy ochrany ovzduší v České republice - seminář č. 2. http://www.ekomonitor.cz/sites/default/files/ obrazky/seminare/ovzdusi/seminar2/10_dil_5b_ tisk_andreovsky.pdf, 2013.

[17] V. Polach. Parní kotle. http://slideplayer.cz/slide/6816422/, 2011.

[18] Výzkumný ústav maltovin Praha, spol. s.r.o., Svaz výrobců cementu ČR. Popílek a jeho použití do betonu. http://www . vumo.cz/wp-content/uploads/2015/05/ popilek_a_jeho_pouziti_do_betonu.pdf 2002.

[19] EN 12350-2, Zkoušení čerstvého betonu - Část 2: Zkouška sednutím. Standard, Úřad pro technickou normalizaci, metrologii a státní zkušebnictví, Praha, 2009.

[20] EN 206-1/Z3, Beton - Č́st 1: Specifikace, vlastnosti, výroba a shoda. Standard, Český normalizační institut, Praha, 2008.

[21] Brio Hranice s.r.o. Omílací buben 0m20f. Machine information system.

[22] BASF STAVEBNÍ HMOTY ČESKÁ REPUBLIKA s.r.o. GLENIUM ACE 40, Technický list, č. 630, 2007.

[23] BASF STAVEBNÍ HMOTY ČESKÁ REPUBLIKA s.r.o. MASTER AIR 178, Technický list, 2015.

[24] EN 12350-7, Zkoušení čerstvého betonu - Část 7: Obsah vzduchu - Tlakové metody. Standard, Úřad pro technickou normalizaci, metrologii a státní zkušebnictví, Praha, 2009.

[25] EN 12390-3, Zkoušení ztvrdlého betonu - Část 3: Pevnost v tlaku zkušebních těles. Standard, Úřad pro technickou normalizaci, metrologii a státní zkušebnictví, Praha, 2009.

[26] ČSN 73 1326, Stanovení odolnosti povrchu cementového betonu proti působení vody a chemických rozmrazovacích látek. Standard, Vydavatelství Úřadu pro normalizaci a měření, Praha, 1984. 